Vol. 6(6), pp. 64-69, October 2014

DOI: 10.5897/J DOH2014.0128

Artic le Number: OBBC 2F748180

ISSN 2006-9871

Copyright (c) 2014

Author(s) retain the copyright of this artic le

http:// www.academic joumals.org/J DOH

\title{
Effectiveness of chlorhexidine and sodium hypochlorite to reduce Enterococcus faecalis biofilm biomass
}

\author{
Julio Cezar Machado Oliveira*, Luis Renan Oliveira Brito and Lucio Souza Gonçalves \\ Postgraduate Program in Dentistry, Estácio de Sá University, Rio de Janeiro, Brazil.
}

Received 3 September, 2014; Received 9 October, 2014

\begin{abstract}
Bacteria present in biofilm show an increased resistance to antimicrobial activity of endodontic irrigants, and the persistence of these microorganisms after chemomechanical preparation may lead to endodontic treatment failure. Thus, the aim of this study was to evaluate the effectiveness of sodium hypochlorite (NaOCl) and chlorhexidine ( $\mathrm{CHX}$ ) to reduce Enterococcus faecalis biofilm biomass. Biofilms built by E. faecalis ATCC 29212 in polystyrene 96-microtiter plate wells were exposed to different concentrations of $\mathrm{NaOCl}(1,2.5$ and $6 \%)$ and $\mathrm{CHX}(0.12,0.2$ and $2 \%)$ for three different time periods (1, 3 and $10 \mathrm{~min})$. The reduction of the biofilm biomass was evaluated by measuring the optical density with a microplate absorbance reader. All the $\mathrm{NaOCl}$ solutions were significantly more effective than any of the CHX solutions tested, regardless of the time of exposure $(P<0.001)$. The three $\mathrm{CHX}$ solutions were not significantly different from the negative control group (PBS) in reducing the biofilm biomass ( $P>0.05$ ); by contrast, after $10 \mathrm{~min}$ of exposure to the $\mathrm{NaOCl}$ the biofilm was not significantly different from the positive control without biofilm $(P>0.05)$. Moreover, considering the period of times used in this study (1 to $10 \mathrm{~min}$ ), no significant differences were observed among different concentrations for each desinfectant. In conclusion, none of the tested concentrations of CHX showed an ability to decrease the biofilm biomass. On the other hand, even the most diluted $\mathrm{NaOCl}$ solution (1\%) reduced the biofilm biomass to a level that was compatible with the complete disruption of the biomass structure.
\end{abstract}

Key words: Sodium hypochlorite, chlorhexidine, biofilm, endodontic infection.

\section{INTRODUCTION}

The aim of endodontic treatment is to control and/or prevent the infection/reinfection of the root canal system (Zerella et al., 2005; Zehnder, 2006; Souza et al., 2010). This can be achieved by proper cleaning, shaping and filling of the root canal and coronal access using sterile instruments, antimicrobial solutions and proper sealing materials (Zehnder, 2006; Gillen et al., 2011).
Endodontists have been offered, over the last few years, an excess of instruments and systems to prepare root canals for cleaning and shaping; however, these new systems have not brought significant improvements regarding antimicrobial effectiveness during irrigation or disinfection of the root canal system (Brito et al., 2009; Pawar et al., 2012). In contrasts with that, studies have 
shown that the disinfection of the root canal system to levels compatible with apical tissue healing is one of the most predictable factors to achieve success in endodontic treatments (Zerella et al., 2005; Siqueira, 2001; Zehnder, 2006; Gillen et al., 2011).

Consequently, any eligible solution to be employed as an endodontic irrigant should exhibit a potent antimicrobial action against fungi, viruses and bacteria (including spore-forming species). Moreover, the ideal irrigant should also be able to promote soft-tissue dissolution without damaging periradicular host tissues (Zehnder, 2006). Although, hitherto, there is no chemical which fits all these requirements, more than $90 \%$ of the North American endodontists have elected sodium hypochlorite $(\mathrm{NaOCl})$ as their first choice irrigant (Dutner et al., 2012).

$\mathrm{NaOCl}$ is a non-specific proteolytic, fungicide, and bactericidal agent. It is strongly alkaline and hypertonic, and although its action is more pronounced on necrotic tissues, $\mathrm{NaOCl}$ also exhibits toxicity on all living tissues, depending on the concentration used and time of exposure (Clarkson and Moule, 1998; Zehnder, 2006). $\mathrm{NaOCl}$ solutions used in endodontics vary in concentrations ranging from 0.5 to $6 \%$, and although the majority of American endodontists prefer concentrations above $5 \%$ (Dutner et al., 2012), previous studies (in vitro and in vivo) have suggested that lower concentrations such as $2.5 \%$ are equally effective in disinfecting the root canal system (Zehnder, 2006; Rôças and Siqueira, 2011).

However, chlorhexidine (CHX) has been recommended as either an alternative or an adjunct root canal irrigant (Zehnder, 2006; Ryan, 2010). CHX is a cationic bisbiguanide that is stable as a salt (usually as chlorhexidine gluconate), and is often used as an endodontic irrigant at concentrations ranging from 0.2 to $2 \%$. It exhibits an optimal antimicrobial activity at $\mathrm{pH}$ ranging from 5.5 to 7.0 (Zerella et al., 2005; Zehnder, 2006; Ryan, 2010). It is a broad-spectrum antimicrobial agent, and offers moderate activity against fungi and viruses (Zehnder, 2006; Ryan, 2010). It also shows some selective action against bacteria, exhibiting a more pronounced effectiveness against Gram-positive cocci, but being less active against Gram-positive and Gram-negative rods (Ryan, 2010). However, $\mathrm{CHX}$ has shown effectiveness against bacteria resistant to calcium hydroxide such as Enterococcus faecalis, and against Gram-negative bacteria commonly recovered from oral cavities (Stowe et al., 2004; Zerella et al., 2005; Mattigatti et al., 2012; Sreenivasan et al., 2013; Wang et al., 2012).

Bacteria participating in an endodontic infection consortium, such as $E$. faecalis, may be organized in a sessile structure as biofilm, or be suspended in fluids (planktonic phase) (Ricucci and Siqueira, 2010). Biofilms have a structure that provides a great protection for bacteria against antimicrobials (Ricucci and Siqueira, 2010), and to eliminate the biofilm containing the associated microorganisms is a challenge to any chemical irrigant.
Thus, the aim of this study was to evaluate the effectiveness of $\mathrm{NaOCl}$ and $\mathrm{CHX}$ to reduce $E$. faecalis biofilm biomass.

\section{MATERIALS AND METHODS}

A standard strain of $E$. faecalis (ATCC 29212) was employed in this work. The Direct Contact Method was chosen to evaluate the effectiveness of each tested solution to reduce the biofilm biomass. The method was adapted from Mohamed et al. (2004). Briefly, a 24-h culture of E. faecalis plated into Trypticase-Soy agar (TSA Difco, Detroit, MI) confirmed the purity of the strain. Then, $E$. faecalis colonies were suspended in sterile distilled water. Fifty microliters of the bacterial suspension, corresponding to $1.5 \times 10^{8}$ colony-forming-units ( $0.5 \mathrm{McF}$ arland scale), were diluted in $5 \mathrm{ml}$ of Trypticase-Soy broth (TSB - Difco, Detroit, MI), supplemented with $0.25 \%$ glucose solution (adapted from Mohamed et al. (2004)). Eight wells of a polystyrene 96-microtiter flatten bottom plate (Nunclon, NUNC A/S, Roskilde, Denmark) were filled with $200 \mu \mathrm{l}$ of sterile TSB (control). Two hundred microliters of the bacterial suspension in TSB were inoculated into each of the remaining wells. After filling the wells, the microtiter was covered with its lid, and left under incubation at $35^{\circ} \mathrm{C}$ for $24 \mathrm{~h}$ in an aerobic atmosphere to allow the building of biofilms in the wells with bacterial suspension. After confirming the presence of biofilm formation in the wells with the bacterial suspension, and the absence of turbidity in the wells only filled with sterile TSB, $100 \mu$ of TSB was removed from the TSB wells by aspiration, and $100 \mu \mathrm{l}$ of phosphate buffered saline (PBS) was added to each of these wells, which served as the positive control group for anti-biofilm effectiveness or absence of biofilm. The negative control group (ineffectiveness in biofilm biomass reduction) consisted of 4 wells where biofilms had been built up. In these negative control wells, $100 \mu$ of TSB was carefully removed by aspiration and replaced by $100 \mu \mathrm{l}$ of PBS, in order to halt the biofilm formation, but preserving it. The remaining 84 wells, presenting biofilms, were used in the disinfectant tests. The TSB was carefully removed from all wells by aspiration, and then they were refilled with one of the following solutions: four different dilutions of $\mathrm{NaOCl}$ solution $(1,2.5$ and $6 \%$ ), or three different dilutions of chlorhexidine gluconate solution ( $0.12,0.2$ and $2 \%)$. These test wells, containing the bacterial biofilms with the different solutions, were maintained for three different time intervals: 1, 3 and $10 \mathrm{~min}$. All of these alternatives (different antimicrobial solutions at different concentrations, and at different time intervals) were quadruplicated ( 4 wells per test). All the groups with their results are shown in Figure 1.

After the exposure to different time intervals, the wells with biofilms were rinsed with PBS, and the remaining biofilm biomass adhering to the well walls was stained with $0.1 \%$ crystal violet solution for $20 \mathrm{~min}$. After that, the excess of dye was washed out with PBS, and the wells were then filled with $95 \%$ ethylic alcohol and placed in a iMark ${ }^{\mathrm{TM}}$ Microplate Absorbance Reader (model \#168-1130XTU, Bio-Rad, Tokyo, Japan) to measure the biofilm biomass based on the optical density of each well at a wavelength of $590 \mathrm{~nm}$.

Statistical analyses were performed using SPSS software (Statistical Package for the Social Sciences, version 17.0, IBM, Chicago, IL). The general linear model (GLM) for repeated measures was used to assess differences among the groups (different concentrations of sodium hypochlorite and chlorhexidine solutions, positive control group - PC, and negative control group NC) for the E. faecalis ATCC 29212 biofilm biomass built up in the three different time intervals $(1,3$, and $10 \mathrm{~min})$. The analyses were adjusted by Tukey's post-hoc test for multiple comparisons. 


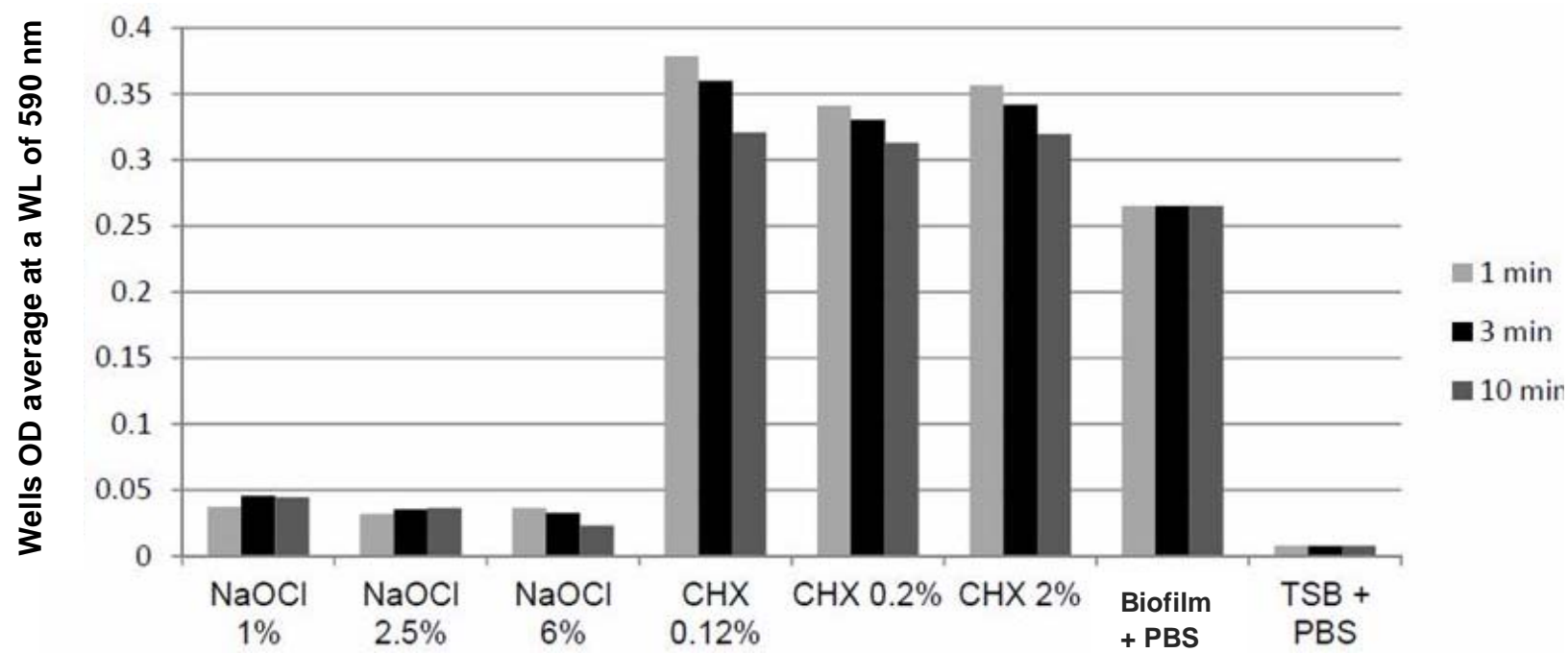

Figure 1. Wells optical density (OD) average at a wavelength (WL) of $590 \mathrm{~nm}$, considering different disinfectant solutions and periods of exposure time.

Table 1. Wells optical density average at a wavelength of $590 \mathrm{~nm}$, considering different disinfectant solutions and periods of exposure time.

\begin{tabular}{lcccccccc}
\hline Time & $\begin{array}{c}\mathrm{NaOCl} \\
\mathbf{( 1 \% )}\end{array}$ & $\begin{array}{c}\mathrm{NaOCl} \\
\mathbf{( 2 . 5 \% )}\end{array}$ & $\begin{array}{c}\mathbf{N a O C l} \\
\mathbf{( 6 \% )}\end{array}$ & $\begin{array}{c}\text { CHX } \\
(\mathbf{0 . 1 2 \% )}\end{array}$ & $\begin{array}{c}\text { CHX } \\
(\mathbf{0 . 2 \%})\end{array}$ & $\begin{array}{c}\text { CHX } \\
\mathbf{( 2 \% )}\end{array}$ & $\begin{array}{c}\text { Biof + } \\
\text { PBS }\end{array}$ & $\begin{array}{c}\text { TSB + } \\
\text { PBS }\end{array}$ \\
\hline $1 \mathrm{~min}$ & 0.037 & 0.032 & 0.036 & 0.378 & 0.341 & 0.356 & 0.265 & 0.008 \\
$3 \mathrm{~min}$ & 0.045 & 0.036 & 0.033 & 0.360 & 0.331 & 0.342 & 0.265 & 0.008 \\
$10 \mathrm{~min}$ & 0.045 & 0.036 & 0.023 & 0.321 & 0.313 & 0.320 & 0.265 & 0.008 \\
\hline
\end{tabular}

Differences were considered significant when $\mathrm{P}<0.05$.

\section{RESULTS}

The comparison among groups (different concentration of sodium hypochlorite and chlorhexidine solution) has shown that all the tested concentrations of $\mathrm{NaOCl}$ were significantly different from the negative control group NC (wells with biofilm and PBS) $(P<0.001)$, and more effective than all of the tested concentrations of $\mathrm{CHX}$, regardless of the time of exposure $(P<0.001)$. Even the lowest concentration of $\mathrm{NaOCl}$ solution (1\%) produced a greater reduction in biofilm biomass than the highest concentration of $\mathrm{CHX}$ solution tested $(2 \%)$, and was not significantly different from the positive control group - PC (without biofilm) after $10 \mathrm{~min}$ of exposure $(P>0.05)$. Conversely, none of $\mathrm{CHX}$ the solutions were able to provide biofilm biomass reduction, and they were not significantly different from NC ( $P>0.05)$ (Table 1).

The analysis within each group regarding the time of exposure has shown no significant differences at any period of time, regardless of the solution concentration (Table 3). Considering $10 \mathrm{~min}$ of biofilm exposure to the disinfectants, there were no significant differences among the different $\mathrm{NaOCl}$ or $\mathrm{CHX}$ concentrations $(\mathrm{P}>0.05)$, within their groups $(\mathrm{NaOCl} \times \mathrm{NaOCl}$ or $\mathrm{CHX} \times \mathrm{CHX})$ (Table 2).

\section{DISCUSSION}

The current study compared the effectiveness of different concentration of $\mathrm{NaOCl}$ and $\mathrm{CHX}$ to reduce $E$. faecalis biofilm biomass. Only $\mathrm{NaOCl}$ solution (all concentration) reduced the biofilm biomass.

Microbial cells may survive within root canal systems after the chemomechanical preparation (Siqueira, 2001; Brito et al., 2009), and substances providing antimicrobial activity for longer periods of time may offer better outcomes. The cationic properties of $\mathrm{CHX}$ give it stability, which can bind to surfaces covered with acidic proteins, such as the hydroxyapatite of dentin, and it is then slowly released at therapeutic levels (Lenet et al., 2000). 
Table 2. Comparisons of the effects of different sodium hypochlorite and chlorhexidine solution on biofilm biomass originated by standard strain of $E$. faecalis ATCC 29212 over three times studied (GLM for repeated measures, standard error $=0.03$ ).

\begin{tabular}{|c|c|c|c|c|c|}
\hline \multicolumn{2}{|c|}{ Comparisons } & \multirow{2}{*}{ Meandifference } & \multirow{2}{*}{$P$ value } & \multirow{2}{*}{\multicolumn{2}{|c|}{$95 \% \mathrm{Cl}$}} \\
\hline Solution A & Solution B & & & & \\
\hline H 1\% & $\mathrm{H} 2.5 \%$ & 0.008 & 1 & -0.08 & 0.10 \\
\hline H 1\% & H 6\% & 0.011 & 1 & -0.08 & 0.10 \\
\hline H $1 \%$ & C $0.12 \%$ & -0.311 & $<0.001$ & -0.40 & -0.22 \\
\hline $\mathrm{H} 1 \%$ & C $0.2 \%$ & -0.286 & $<0.001$ & -0.38 & -0.19 \\
\hline H $1 \%$ & C $2 \%$ & -0.297 & $<0.001$ & -0.39 & -0.20 \\
\hline H $1 \%$ & NC & -0.222 & $<0.001$ & -0.32 & -0.13 \\
\hline H 1\% & PC & 0.035 & 0.959 & -0.06 & 0.13 \\
\hline H $2.5 \%$ & H 6\% & 0.004 & 1 & -0.09 & 0.10 \\
\hline H $2.5 \%$ & C $0.12 \%$ & -0.318 & $<0.001$ & -0.41 & -0.22 \\
\hline H $2.5 \%$ & C $0.2 \%$ & -0.294 & $<0.001$ & -0.39 & -0.20 \\
\hline H $2.5 \%$ & C $2 \%$ & -0.305 & $<0.001$ & -0.40 & -0.21 \\
\hline H $2.5 \%$ & NC & -0.230 & $<0.001$ & -0.33 & -0.14 \\
\hline H 2.5\% & PC & 0.027 & 0.992 & -0.07 & 0.12 \\
\hline H 6\% & C $0.12 \%$ & -0.322 & $<0.001$ & -0.41 & -0.23 \\
\hline H 6\% & C $0.2 \%$ & -0.297 & $<0.001$ & -0.39 & -0.20 \\
\hline H $6 \%$ & C $2 \%$ & -0.308 & $<0.001$ & -0.40 & -0.21 \\
\hline H $6 \%$ & NC & -0.230 & $<0.001$ & -0.33 & -0.14 \\
\hline H $6 \%$ & PC & 0.023 & 0.997 & -0.07 & 0.12 \\
\hline C $0.12 \%$ & C $0,2 \%$ & 0.025 & 1 & -0.12 & -0.07 \\
\hline C $0.12 \%$ & C $2 \%$ & 0.014 & 1 & -0.10 & -0.08 \\
\hline C $0.12 \%$ & NC & 0.088 & 0.111 & -0.01 & 0.18 \\
\hline C $0.12 \%$ & PC & 0.345 & $<0.001$ & 0.25 & 0.44 \\
\hline C $0.2 \%$ & C $2 \%$ & -0.011 & 1 & -0.10 & 0.08 \\
\hline C $0.2 \%$ & NC & 0.063 & 0.453 & -0.03 & 0.16 \\
\hline C $0.2 \%$ & PC & 0.320 & $<0.001$ & 0.23 & 0.42 \\
\hline C $2 \%$ & NC & 0.074 & 0.242 & -0.02 & 0.17 \\
\hline C 2\% & PC & 0.332 & $<0.001$ & 0.24 & 0.43 \\
\hline
\end{tabular}

$\mathrm{H}=$ Sodium hypochlorite; $\mathrm{C}=$ chlorhexidine; $\mathrm{PC}=$ positive control (saline solution on biofilm); $\mathrm{NC}=$ negative control (saline solution on medium without biofilm); $\mathrm{Cl}=$ confidence interval; $\mathrm{Cl}$ was adjusted by Tukey's post-hoc test for multiple comparisons.

Table 3. Comparisons of the effects over time on the biofilm biomass originated by $E$. faecalis ATCC 29212 , within each group (GLM repeated measures)

\begin{tabular}{lccc}
\hline \multirow{2}{*}{ Irrigant solution } & \multicolumn{3}{c}{ Time intervals (P value) } \\
\cline { 2 - 4 } & T1 - T2 & T2 - T3 & T1 - T3 \\
\hline H 1\% & 0.364 & 0.937 & 0.351 \\
H 2.5\% & 0.680 & 0.934 & 0.750 \\
H 6\% & 0.653 & 0.206 & 0.215 \\
C 0.12\% & 0.213 & 0.179 & 0.108 \\
C 0.2\% & 0.585 & 0.581 & 0.376 \\
C 2\% & 0.345 & 0.223 & 0.199 \\
\hline
\end{tabular}

The $P$ value was adjusted by least significant difference (LSD) test for multiple comparisons. $\mathrm{H}=$ Sodium hypochlorite; $\mathrm{C}=$ chlorhexidine. 
However, considering that bacteria organized as biofilm show greater resistance to antimicrobials than those in the planktonic phase, the antimicrobial activity of the irrigant may be impaired if this chemical is not able to dissolve tissues and biofilms. Sena et al. (2006) investigated the antimicrobial activity of $5.25 \% \mathrm{NaOCl}$ and $2 \% \mathrm{CHX}$ as endodontic-irrigating substances against selected single-species biofilms, and did not find any significant differences between them. Lima et al. (2001) employed three-day biofilms of $E$. faecalis induced on cellulose nitrate membrane filters and found that $\mathrm{CHX}$ was as effective as $\mathrm{NaOCl}$ in killing bacterial cells. Our results showed that $\mathrm{NaOCl}$, regardless of the concentration employed, promoted greater reduction on biofilm biomass than $\mathrm{CHX}$; even the lowest concentration of $\mathrm{NaOCl}$ solution $(0.1 \%)$ exerted a greater reduction of the biofilm biomass than the highest concentration of $\mathrm{CHX}$ tested $(2 \%)$. These results were corroborated by Ordinola-Zapata et al. (2012). These authors employed confocal microscopy to evaluate bacterial cell viability after the exposure of oral bacteria biofilm to $\mathrm{NaOCl}$ and $\mathrm{CHX}$, and showed that $\mathrm{NaOCl}$ was pronouncedly more effective than $\mathrm{CHX}$ to kill bacteria cells organized in biofilm (Ordinola-Zapata et al., 2012).

Other studies that have compared the effectiveness of $\mathrm{NaOCl}$ and $\mathrm{CHX}$ against $E$. faecalis showed that $\mathrm{CHX}$ was as effective as, or even more effective than $\mathrm{NaOCl}$, but these studies did not use a method based on antimicrobial activity against biofilms (Vianna and Gomes, 2009), or used unreliable methods such as the agar diffusion test (Poggio et al., 2012; Mattigatti et al., 2012; Sassone et al., 2008). However, it has been clearly shown that bacteria are usually organized in biofilm structures or within necrotic pulp tissue remnants in the root canal system (Baldasso et al., 2012; Vera et al., 2012; Ricucci and Siqueira, 2010; Ricucci et al., 2009), and these tissues/structures may protect bacterial cells against antimicrobial action.

$\mathrm{CHX}$ has been proposed as an alternative irrigant solution to $\mathrm{NaOCl}$ (Zehnder, 2006; Ryan, 2010). CHX is known to have a low toxicity to host tissues (Stowe et al., 2004; Zehnder, 2006; Ryan, 2010) exhibiting less cytotoxicity than $\mathrm{NaOCl}$, although some issues have been raised regarding its supposed biocompatibility (Chang et al., 2001; Trevino et al., 2011). Indeed, Trevino et al. (2011) showed that $\mathrm{CHX}$ may cause an inflammatory response in periradicular tissues if extruded beyond the root canal apex, even when minimal $\mathrm{CHX}$ concentrations such as $0.1 \%$ are used. Other studies have also shown that even at low concentrations such as $0.12 \%, \mathrm{CHX}$ induces inflammatory response in subcutaneous tissues of guinea pigs, ranging from mild/moderated reaction to foreign body granuloma formation or tissue death, and these levels of reactions are positively correlated with the concentration of $\mathrm{CHX}$ used (Zehnder, 2006; Faria et al., 2007).
The data reported in the present investigation should be interpreted with caution due to the limitations of an in vitro study to reproduce a normal biological condition. In addition, further studies should also evaluate if the addition of biofilm disrupting components to $\mathrm{CHX}$ solutions would provide a thorough removal of biofilm, equivalent to that provided by $\mathrm{NaOCl}$ solutions.

\section{Conclusion}

None of the tested concentrations of $\mathrm{CHX}$ showed an ability to decrease the biofilm biomass. On the other hand, even the most diluted $\mathrm{NaOCl}$ solution $(0.5 \%)$ reduced the biofilm biomass to a level that was compatible with the complete disruption of the biomass structure.

\section{ACKNOWLEDGEMENTS}

The authors thank Marlei Gomes da Silva and José Freitas Siqueira Junior for their technical support to this study. This study was supported by grants from Fundação Carlos Chagas Filho de Amparo à Pesquisa do Estado do Rio de Janeiro (FAPERJ), Brazilian governmental institution.

\section{Conflict of Interest}

The authors declare no conflicts of interest related to this study.

\section{REFERENCES}

Baldasso FE, Stürmer CP, Luisi SB, Petruzzi MN, Scarparo RK, De Figueiredo JA (2012). Microflora associated with primary endodontic infections: correlations among SEM evaluation, clinical features, and radiographic findings. Microsc. Res. Tech. 75(11):1557-1563. biofilms. Int. Endod. J. 39(11):878-885.

Brito PR, Souza LC, Machado de Oliveira JC, Alves FR, De-Deus G, Lopes HP, Siqueira JF Jr (2009). Comparison of the effectiveness of three irrigation techniques in reducing intracanal Enterococcus faecalis populations: an in vitro study. J. Endod. 35(10):1422-1427.

Chang YC, Huang FM, Tai KW, Chou MY (2001). The effect of sodium hypochlorite and chlorhexidine on cultured human periodontal ligament cells. Oral Surg. Oral Med. Oral Pathol. Oral Radiol. Endod. 92(4):446-450.

Clarkson RM, Moule AJ (1998). Sodium hypochlorite and its use as an endodontic irrigant. Aust. Dent. J. 43(4):250-256.

Dutner J, Mines P, Anderson A (2012). Irrigation trends among American Association of Endodontists members: a web-based survey. J. Endod. 38(1):37-40.

Faria G, Celes MR, De Rossi A, Silva LA, Silva JS, Rossi MA (2007). Evaluation of chlorhexidine toxicity injected in the paw of mice and added to cultured L929 fibroblasts. J. Endod. 33(6):715-722. Gillen BM, Looney SW, Gu LS, Loushine BA, Weller RN, Loushine RJ, Pashley DH, Tay FR (2011). Impact of the quality of coronal restoration versus the quality of root canal fillings on success of root canal treatment: a systematic review and meta-analysis. J. Endod. 37(7):895-902. 
Lenet BJ, Komorowski R, Wu XY, Huang J, Grad H, Lawrence HP, Friedman S (2000). Antimicrobial substantivity of bovine root dentin exposed to different chlorhexidine delivery vehicles. J. Endod. 26(11):652-655.

Lima KC, Fava LR, Siqueira JF Jr (2001). Susceptibilities of Enterococcus faecalis biofilms to some antimicrobial medications. J. Endod. 27(10):616-619.

Mattigatti S, Ratnakar P, Moturi S, Varma S, Rairam S (2012). Antimicrobial effect of conventional root canal medicaments vs propolis against Enterococcus faecalis, Staphylococcus aureus and Candida albicans. J. Contemp. Dent. Pract. 13(3):305-309.

Mohamed JA, Huang W, Nallapareddy SR, Teng F, Murray BE (2004). Influence of origin of isolates, especially endocarditis isolates, and various genes on biofilm formation by Enterococcus faecalis. Infect. Immun. 72(6):3658-3663.

Ordinola-Zapata R, Bramante CM, Cavenago B, Graeff MS, Gomes de Moraes I, Marciano M, Duarte MA (2012). Antimicrobial effect of endodontic solutions used as final irrigants on a dentine biofilm model. Int. Endod. J. 45(2):162-168.

Pawar R, Alqaied A, Safavi K, Boyko J, Kaufman B (2012). Influence of an apical negative pressure irrigation system on bacterial elimination during endodontic therapy: a prospective randomized clinical study. J. Endod. 38(9):1177-1181.

Poggio C, Colombo M, Scribante A, Sforza D, Bianchi S (2012). In vitro antibacterial activity of different endodontic irrigants. Dent. Traumatol. 28(3):205-209.

Ricucci D, Siqueira JF Jr (2010). Biofilms and apical periodontitis: study of prevalence and association with clinical and histopathologic findings. J. Endod. 36(8):1277-1288.

Ricucci D, Siqueira JF Jr, Bate AL, Pitt Ford TR (2009). Histologic investigation of root canal-treated teeth with apical periodontitis: a retrospective study from twenty-four patients. J. Endod. 35(4):493502.

Rôças IN, Siqueira JF Jr (2011). Comparison of the in vivo antimicrobial effectiveness of sodium hypochlorite and chlorhexidine used as root canal irrigants: a molecular microbiology study. J. Endod. 37(2):143150.

Ryan S (2010). Chlorhexidine as a canal irrigant: a review. Compend. Contin. Educ. Dent. 31(5):338-342.

Sassone LM, Fidel RA, Murad CF, Fidel SR, Hirata R Jr (2008). Antimicrobial activity of sodium hypochlorite and chlorhexidine by two different tests. Aust. Endod. J. 34(1):19-24.

Sena NT, Gomes BP, Vianna ME, Berber VB, Zaia AA, Ferraz CC, Souza-Filho FJ (2006). In vitro antimicrobial activity of sodium hypochlorite and chlorhexidine against selected single-species
Siqueira JF Jr (2001). Aetiology of root canal treatment failure: why well-treated teeth can fail. Int. Endod. J. 34(1):1-10.

Souza LC, Brito PR, de Oliveira JC, Alves FR, Moreira EJ, SampaioFilho HR, Rôças IN, Siqueira JF Jr (2010). Photodynamic therapy with two different photosensitizers as a supplement to instrumentation/irrigation procedures in promoting intracanal reduction of Enterococcus faecalis. J. Endod. 36(2):292-296.

Sreenivasan PK, Haraszthy VI, Zambon JJ (2013). Antimicrobial efficacy of $0.05 \%$ cetylpyridinium chloride mouthrinses. Lett. Appl. Microbiol. 56(1):14-20.

Stowe TJ, Sedgley CM, Stowe B, Fenno JC (2004). The effects of chlorhexidine gluconate $(0.12 \%)$ on the antimicrobial properties of tooth-colored ProRoot mineral trioxide aggregate. J. Endod. 30(6):429-431.

Trevino EG, Patwardhan AN, Henry MA, Perry G, Dybdal-Hargreaves $N$, Hargreaves KM, Diogenes A (2011). Effect of irrigants on the survival of human stem cells of the apical papilla in a platelet-rich plasma scaffold in human root tips. J. Endod. 37(8):1109-1115

Vera J, Siqueira JF Jr, Ricucci D, Loghin S, Fernández N, Flores B, Cruz AG (2012). One- versus two-visit endodontic treatment of teeth with apical periodontitis: a histobacteriologic study. J. Endod. 38(8):1040-1045.

Vianna ME, Gomes BP (2009). Efficacy of sodium hypochlorite combined with chlorhexidine against Enterococcus faecalis in vitro. Oral Surg. Oral Med. Oral Pathol. Oral Radiol. Endod. 107(4):585589.

Wang Z, Shen Y, Haapasalo M (2012). Effectiveness of endodontic disinfecting solutions against young and old Enterococcus faecalis biofilms in dentin canals. J. Endod. 38(10):1376-1379.

Zehnder M (2006). Root canal irrigants. J.Endod.32(5):389-398.

Zerella JA, Fouad AF, Spångberg LS (2005). Effectiveness of a calcium hydroxide and chlorhexidine digluconate mixture as disinfectant during retreatment of failed endodontic cases. Oral Surg. Oral Med. Oral Pathol. Oral Radiol. Endod.100(6):756-761. 